\title{
Pengolahan Air Limbah Domestik menggunakan Biosand Filter
}

\author{
Rhenny Ratnawati ${ }^{1}$ dan Sakbanul Lailatul Ulfah ${ }^{1}$
}

${ }^{1}$ Program Studi Teknik Lingkungan, Fakultas Teknik Sipil dan Perencanaan, Universitas PGRI Adi Buana Surabaya; e-mail: ratnawati@unipasby.ac.id

\begin{abstract}
ABSTRAK
Biosand filter merupakan alternatif teknologi pengolahan air limbah. Penelitian ini bertujuan untuk: 1) Menganalisis efisiensi biosand filter menggunakan variasi komposisi dan ketinggian media dan 2) Membandingkan variasi komposisi dan ketinggian media yang paling efektif selama pengolahan menggunakan biosand filter. Penelitian ini menggunakan dua reaktor yang masing-masing berdimensi $(30 \times 30 \times 100) \mathrm{cm}$ dengan adanya variasi komposisi dan ketinggian media. Susunan media yang digunakan pada kedua reaktor terdiri dari media kerikil:pasir kasar:pasir halus:karbon aktif. Reaktor 1 mempunyai ketinggian masing-masing adalah (10:10:30:10) cm untuk media kerikil:pasir kasar:pasir halus:karbon aktif. Reaktor 2 media kerikil:pasir kasar:pasir halus:karbon aktif dengan masing-masing ketinggian adalah (10:10:15:25) cm. Filter dioperasikan secara batch dengan memanfaatkan gaya gravitasi. Pengambilan sampel dilakukan selama 20 hari dimulai dari hari ke-0, 5, 10, 15, dan 20. Hasil penelitian menunjukkan bahwa efisiensi penurunan konsentrasi BOD dan TSS pada reaktor 1 dengan susunan media kerikil:pasir kasar:pasir halus:karbon aktif (10:10:30:10) cm berturut-turut adalah 62,92\% dan 78,40\%. Pada reaktor 2 dengan susunan media kerikil:pasir kasar:pasir halus:karbon aktif (10:10:15:25) cm mempunyai nilai efisiensi penurunan konsentrasi BOD dan TSS masing-masing adalah 67,01\% dan 81,99\%. Variasi susunan media yang lebih efektif dalam menurunkan konsentrasi BOD dan TSS pada air limbah domestik adalah reaktor 2 dengan media kerikil:pasir kasar:pasir halus:karbon aktif dengan ketinggian $(10: 10: 15: 25) \mathrm{cm}$.
\end{abstract}

Kata kunci: Air limbah domestik, Biological Oxygen Demand, Biosand filter, Total Suspended Solid

\begin{abstract}
Biosand filter is an alternative technology for processing wastewater. The aims of this research are: 1) to analyze the efficiency of biosand filter using variations in composition and height of the media and 2) to compare variations in composition and height of the most effective during processing using biosand filter. This study uses two reactors, each of which uses dimensions of $(30 \times 30 \times 100) \mathrm{cm}$ in the presence of variations in the height of the media. The composition of the media used in both reactors consisted of gravel:coarse sand:fine sand:activated carbon. Reactor 1 has a height of respectively (10:10:30:10) cm for gravel:coarse sand:fine sand:activated carbon. Reactor 2 of gravel:coarse sand:fine sand:activated carbon with each height is $(10: 10: 15: 25) \mathrm{cm}$. Filters are operated in batches using the force of gravity. Sampling was carried out for 20 days starting from days $0,5,10,15$, and 20 days. The results showed that the efficiency of reducing BOD and TSS concentrations in reactor 1 with the composition of gravel:coarse sand:fine sand:activated carbon (10:10:30:10) cm were $62.92 \%$ and $78,40 \%$ respectively. In reactor 2 with a composition of gravel:coarse sand:fine sand:activated carbon (10:10:15:25) cm have efficiency values to decrease BOD and TSS concentrations respectively are $67.01 \%$ and $81.99 \%$. Variations in the composition of the media that are more effective in decreased the concentration of BOD and TSS in domestic wastewater are gravel:coarse sand:fine sand:activated carbon with a height of $(10: 10: 15: 25) \mathrm{cm}$.
\end{abstract}

Keywords: Domestic wastewater, Biological Oxygen Demand, Biosand filter, Total Suspended Solid

Citation: Ratnawati, R., dan Ulfah, S. L. (2020). Pengolahan Air Limbah Domestik menggunakan Biosand Filter. Jurnal Ilmu Lingkungan, 18(1), 8-14, doi:10.14710/jil.18.1.8-14

\section{Pendahuluan}

Air limbah domestik mengandung bahan organik (protein, kaborhidrat, dan lemak) dan anorganik (butiran, garam, dan metal) baik tersuspensi maupun terlarut (Kodoatie dkk., 2010). Belum adanya pengolahan pada air limbah, langsung dibuang ke sungai (Nurhayati dkk., 2019). Hal ini yang dapat menyebabkan penurunan kualitas baik air, air tanah, maupun tanah, merusak ekosistem perairan, penurunan tingkat estetika suatu wilayah, dan timbulnya bau (Samina dkk., 2013; Nurhayati dkk., 2019).

Biosand filter adalah alternatif teknologi dengan biaya relatif terjangkau yang diaplikasikan untuk pengolahan air limbah (Nogarh dkk., 2015). Pengolahan dengan biosand filter sesuai mengolah air limbah yang mempunyai kandungan bahan organik tinggi (Suligundi, 2013; Rahmi, 2016). Sumber air biosand filter dapat digunakan dengan sumber air 
apapun seperti air hujan, air tanah dalam, air tanah dangkal, sungai, danau atau permukaan lainnya Ulum dkk., 2015; Rahmi, 2016). Biosand filter sesuai digunakan dalam skala rumah tangga karena bentuknya lebih kecil dan diadaptasi untuk penggunaan intermittent (Center for Affordable Water and Sanitation Technologie, 2010). Reaktor biosand filter dapat menurunkan konsentrasi COD dan Escherichia coli masing-masing adalah $60 \%$ dan $80 \%$ (Lynn dkk., 2013). Kubare dan Haarhoff (2010) menyatakan bahwa biosand filter mempunyai efisiensi penurunan virus dan parasit sampai dengan $90 \%$, efisiensi penurunan besi dan mangan sebesar 0,75\%. Lapisan biofilm yang tumbuh di permukaan media paling atas pada biosand filter ini dapat menurunkan rasa, bau, dan warna (Center for Affordable Water and Sanitation Technologie, 2010).

Penelitian yang dilakukan oleh Puspitahati dkk. (2012), Halim (2014), Lusela dkk. (2015) berhasil mengolah air limbah dengan sistem biosand filter. Penelitian yang dilakukan oleh Puspitahati dkk. (2012) mengolah limbah laundry menggunakan biosand filter mempunyai nilai efisiensi penurunan konsentrasi fosfat sebesar 13,90-19,80\%. Biosand filter dengan media karbon aktif dalam mengolah limbah laundry diperoleh efisiensi penurunan konsentrasi TSS sebesar 82,65\% (Halim, 2014). Lusela dkk. (2015) menggunakan biosand filter dalam mengolah air limbah rumah makan (restoran) mampu menurunkan BOD sebesar 65,13\%. Penelitian ini bertujuan untuk: 1) Menganalisis efisiensi biosand filter menggunakan variasi komposisi dan ketinggian media dan 2) Membandingkan variasi komposisi dan ketinggian media yang paling efektif selama pengolahan menggunakan biosand filter.

\section{Metode Penelitian \\ 2.1 Alat}

Reaktor biosand filter terbuat dari kaca. Ketebalan pada reaktor adalah $0,8 \mathrm{~cm}$. Reaktor tersebut dilengkapi dengan bak penampung air berupa bak plastik, pipa PVC dan sambungannya, pengatur debit, diffusure plate, dan kran. Detail reaktor disajikan pada Gambar 1.

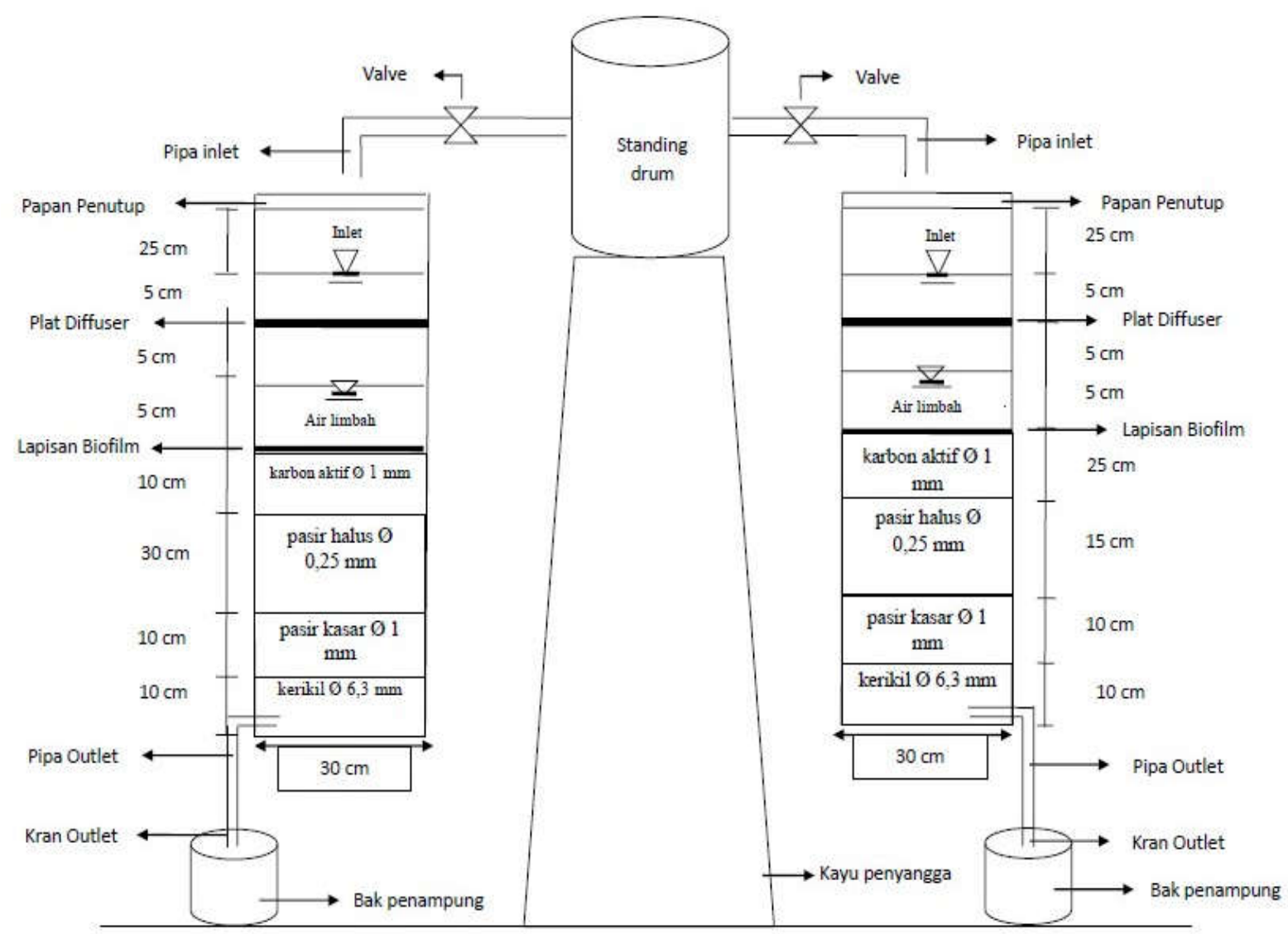

Gambar 1. Reaktor Biosand Filter

\subsection{Bahan}

Bahan berupa air limbah domestik yang berasal dari dua titik saluran drainase yang berada pada Desa Warugunung RT 05/RW 03 Kecamatan Karang Pilang Kota Surabaya Gang 8D dan 8E. Media biosand filter yang digunakan adalah karbon aktif granular. Pasir kasar dan halus masing-masing berdiameter $1 \mathrm{~mm}$ (mesh ukuran 20) dan 0,25 mm (mesh ukuran 60). Media penyangga kerikil dengan diameter $6 \mathrm{~mm}-15$ mm. Media biosand filter yang sudah diayak sesuai 
dengan diameter butiran, dicuci dengan air bersih, dikeringkan, selanjutnya dimasukkan ke dalam reaktor secara bertahap.

\subsection{Seeding dan Aklimatisasi}

Seeding atau pembenihan dan aklimatisasi atau pengadaptasian dilakukan secara alami dengan memasukan air limbah domestik ke dalam media filter. Proses seeding dan aklimatisasi dilakukan untuk melihat pertumbuhan mikrooganisme berupa lapisan biofilm yang muncul (Ratnawati dan Kholif, 2018). Ketinggian air di atas permukaan media setinggi $5 \mathrm{~cm}$ dijaga agar lapisan biofilm muncul pada reaktor biosand filter. Uji permanganat dilakukan untuk menentukan adanya lapisan biofilm yang mengindikasikan pertumbuhan bakteri.

\subsection{Pengoperasian Biosand Filter}

Biosand filter dioperasikan secara batch. Langkah pengoperasian biosand filter sebagai berikut:

a. Air limbah domestik dihomogenkan lalu dituang ke dalam bak pengumpul berupa standing drum.

b. Air limbah domestik yang berada pada bak pengumpul dialirkan ke dalam reaktor menggunakan pipa yang diberi debit pengatur agar debit tetap konstan kemudian dialirkan ke dalam reaktor 1 dan 2 .

c. Variasi penelitian berupa perbedaan jenis dan ketinggian media. Reaktor 1 dengan media kerikil:pasir kasar:pasir halus:karbon aktif adalah (10:10:30:10) cm. Reaktor 2 dengan media kerikil:pasir kasar:pasir halus:karbon aktif adalah (10:10:15:25) $\mathrm{cm}$.

d. Ketinggian air limbah domestik dalam reaktor tetap dijaga $\pm 5 \mathrm{~cm}$ diatas plat diffuser. e. Pengambilan sampel diambil pada hari ke-0, 5, 10, 15, dan 20 hari dengan dilakukan pengulangan duplo. Titik pengambilan sampel yaitu inlet, outlet 1 dan 2. Parameter yang diteliti adalah kadar BOD dan TSS.

\section{Hasil dan Pembahasan}

\subsection{Karakteristik Air Limbah Domestik}

Konsentrasi BOD, TSS, pH, dan suhu awal air limbah domestik masing-masing adalah $60,71 \mathrm{mg} / \mathrm{L}$, $103 \mathrm{mg} / \mathrm{L}, 7,38$ dan $29^{\circ} \mathrm{C}$ (Tabel 1). Konsentrasi BOD dan TSS tersebut melebihi baku mutu yang dipersyaratkan berdasarkan Peraturan Menteri Lingkungan Hidup dan Kehutanan Republik Indonesia Nomor 68 Tahun 2016 tentang Baku Mutu Air Limbah Domestik. Baku mutu konsentrasi BOD dan TSS adalah $30 \mathrm{mg} / \mathrm{L}$ dan $50 \mathrm{mg} / \mathrm{L}$, sedangkan air limbah domestik mempunyai konsentrasi BOD dan TSS bernilai 60,71 mg/L dan 103 mg/L. Konsentrasi BOD air limbah yang tinggi dikarenakan tingginya kandungan organik, hal ini mengakibatkan kebutuhan jumlah gas oksigen meningkat. Semakin tinggi konsentrasi BOD, maka semakin sedikit mikroorganisme yang hidup didalamnya (Nurhayati dkk., 2019). Menurut Halim (2014) konsentrasi BOD yang tinggi tersebut merupakan gambaran bahwa bahan organik telah mencemari lingkungan, maka dari itu perlu dilakukan adanya pengolahan.

Konsentrasi TSS yang tinggi dikarenakan adanya padatan tersuspensi yang mengandung molekul surfaktan, sabun, dan deterjen (Kholif dan Ratnawati, 2017). Tingginya konsentrasi TSS menghalangi masuknya cahaya matahari pada suatu perairan, juga menyebabkan pendangkalan badan air karena meningkatnya sedimen (Widyaningsih, 2011).

Tabel 1. Karakteristik Awal Air Limbah Domestik

\begin{tabular}{clccc}
\hline No & \multicolumn{1}{c}{ Parameter } & Satuan & Hasil & Baku Mutu* $^{*}$ \\
\hline 1 & BOD & $\mathrm{mg} / \mathrm{L}$ & $\mathbf{6 0 , 7 1}$ & 30 \\
2 & Zat Tersuspensi (TSS) & $\mathrm{mg} / \mathrm{L}$ & $\mathbf{1 0 3}$ & 50 \\
3 & $\mathrm{pH}$ & - & 7,38 & $6-9$ \\
4 & Suhu & ${ }^{\circ} \mathrm{C}$ & 29 & Deviasi \\
\hline
\end{tabular}

Keterangan: *Peraturan Menteri Lingkungan Hidup dan Kehutanan Republik Indonesia Nomor 68 Tahun 2016 tentang Baku Mutu Air Limbah Domestik.

\subsection{Hasil Seeding dan Aklimatisasi}

Hasil uji permanganat yang digunakan untuk uji pertumbuhan bakteri disajikan pada Gambar 2 . Seeding dilakukan selama 10 hari, waktu ini lebih cepat apabila dibandingkan dengan penelitian sebelumnya karena pertumbuhan mikroorganisme di dalam reaktor tumbuh dan berkembang dengan cepat. Penelitian yang dilakukan oleh Halim (2014) melaporkan bahwa proses seeding dilakukan selama 12 hari pada pengolahan limbah cair laundry dengan media karbon aktif. 


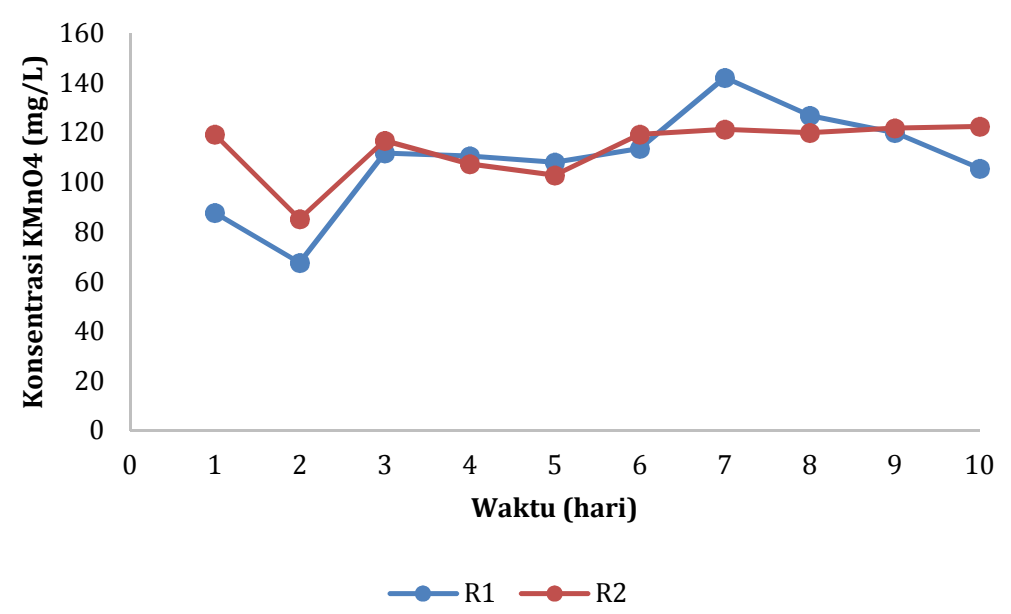

Gambar 2. Pertumbuhan Biofilm Selama Proses Seeding

Keterangan: R1 = kerikil:pasir halus:pasir kasar:karbon aktif $=(10: 10: 30: 10) \mathrm{cm}$

$\mathrm{R} 2=$ kerikil:pasir halus:pasir kasar:karbon aktif $=(10: 10: 15: 25) \mathrm{cm}$

Pertumbuhan biofilm selama proses seeding yaitu hari ke-3 pertumbuhan mikroorganisme mulai terjadi, baik pada reaktor 1 maupun 2. Pada reaktor 1 , hari ke-7 sampai dengan ke-10 proses seeding terjadi sedikit penurunan konsentrasi $\mathrm{KMnO}_{4}$. Penurunan ini menunjukkan nutrien terbatas pada reaktor, tetapi mampu memenuhi makanan bakteri (Utami, 2013). Kondisi konsentrasi $\mathrm{KMnO}_{4}$ yang mulai stabil pada hari ke-7 sampai akhir proses mengindikasikan bahwa telah tercapai konsidi steady state, dimana kondisi mikrooganisme sudah dapat dilakukan running. Kondisi stabil pertumbuhan mikroorganisme pada reaktor 2 terjadi pada hari ke6 sampai akhir pengamatan. Hal tersebut menunjukkan bahwa mikroorganisme dapat beradaptasi dan berkembang baik, sehingga mikroorganisme siap untuk melakukan proses running (Ananda, dkk 2017). Volume reaktor, nutrient, dan substrat yang terbatas menjadi penghambat pertumbuhan bakteri (Suligundi, 2013).

\subsection{Konsentrasi BOD pada Reaktor Biosand Filter}

Rata-rata konsentrasi BOD pada kedua reaktor perlahan-lahan menurun dari awal sampai dengan akhir penelitian (Gambar 3a). Hari ke-15 penelitian terlihat bahwa rata-rata konsentrasi BOD pada kedua reaktor telah memenuhi baku mutu yang dipersyaratkan menurut Peraturan Menteri Lingkungan Hidup dan Kehutanan Republik Indonesia Nomor 68 Tahun 2016 bernilai 37,57 mg/L dan 26,13 mg/L untuk reaktor 1 dan 2. Pada awal penelitian lapisan biofilm yang ditumbuhi oleh mikroorganisme masih beradaptasi sehingga zat organik dalam reaktor biosand filter belum optimal karena keterbatasan sumber energi dan nutrisi yang tersedia (Lusela dkk., 2015).
Rata-rata konsentrasi BOD akhir pada reaktor 1 dan reaktor 2 berturut-turut adalah 22,51 mg/L dan 20,03 mg/L. Penurunan konsentrasi BOD pada biosand filter terjadi karena adanya proses adsorbsi yang terjadi pada media biosand filter. Mikroorganisme yang ada pada reaktor menguraikan bahan organik menjadi bentuk yang lebih sederhana (Hidayah dkk., 2018). Lapisan biofilm yang mengandung mikroorganisme berfungsi dalam menguraikan zat-zat organik pada air limbah (Widyaningsih, 2011). Rhenny dan Kholif (2018) menyatakan bahwa pertumbuhan mikroorganisme membutuhkan sumber nutrien dari bahan organik, hal ini yang menyebabkan bahan organik mengalami penurunan. Penurunan konsentrasi BOD kemungkinan terjadi karena pengaruh media kerikil yang membantu untuk menangkap dan mengendapkan material partikulat.

Efisiensi penurunan konsentrasi BOD pada reaktor kedua reaktor tertinggi terjadi pada hari ke20 yaitu berturut-turut $62,92 \%$ dan $67,01 \%$ untuk reaktor 1 dan 2. (Gambar 3b). Menurut Kholif dan Ratnawati (2016) bahwa efisiensi penurunan konsentrasi BOD pada hari ke-20 merupakan kondisi optimum pertumbuhan mikroorganisme. Selain mikroorganisme yang bekerja pada kondisi optimum, perbedaan efisiensi juga dipengaruhi oleh tinggi media biosand filter. Menurut Ulfa (2010), semakin tebal atau tinggi media dalam filter maka efektivitas penurunan konsentrasi pencemar semakin tinggi. Penelitian yang dilakukan Ronny dan Syam (2018) juga mengalami penurunan dengan persentase ratarata sebesar 39,97\% dengan menggunakan media saringan pasir silika dan karbon aktif. Adanya penurunan ini dipengaruhi oleh media tersebut dimana saringan pasir silika dan karbon aktif mempunyai kemampuan ganda seperti melakukan 
proses filtrasi, adsorpsi dan menukar ion secara bersamaan sehingga mampu mengurai dan menurunkan beban pencemar dalam limbah cair.

Jika dibandingkan kedua reaktor, reaktor 2 mempunyai efisiensi penurunan konsentrasi BOD yang lebih tinggi dibandingkan reaktor 1 . Ketebalan suatu media sangat memberikan pengaruh terhadap penurunan konsentrasi BOD dimana semakin tebal media karbon aktif, maka semakin tinggi penurunan yang terjadi Hal ini dikarenakan media karbon aktif memiliki peningkatan efisiensi yang lebih tinggi karena luas permukaan yang kecil dan daya serap beban pencemar yang tinggi (Kholif dan Ratnawati, 2017). Media karbon aktif dihasilkan dari pemanasan suhu tinggi dari bahan yang mengandung karbon merupakan padatan berpori dengan konsentrasi karbon 85-95\% (Gultom dan Lubis, 2014). Karbon aktif telah berhasil diteliti untuk menurunkan logam berat, bau, warna, dan pengotor organik lainnya (Said, 2010; Nurhayati dkk., 2018). Besar atau volume pori dan luas permukaan merupakan parameter kunci adsorpsi karbon aktif (Jamilatun dan Setyawan, 2014).

Gultom dan Lubis (2014) menyatakan bahwa karbon aktif merupakan padatan berpori dengan kadar karbon sebesar 85-95\%. Media ini dihasilkan dari pemanasan suhu tinggi. kegunaan karbon aktif adalah menurunkan pengotor organik, warna, bau, dan logam berat (Said, 2010; Nurhayati dkk., 2018).

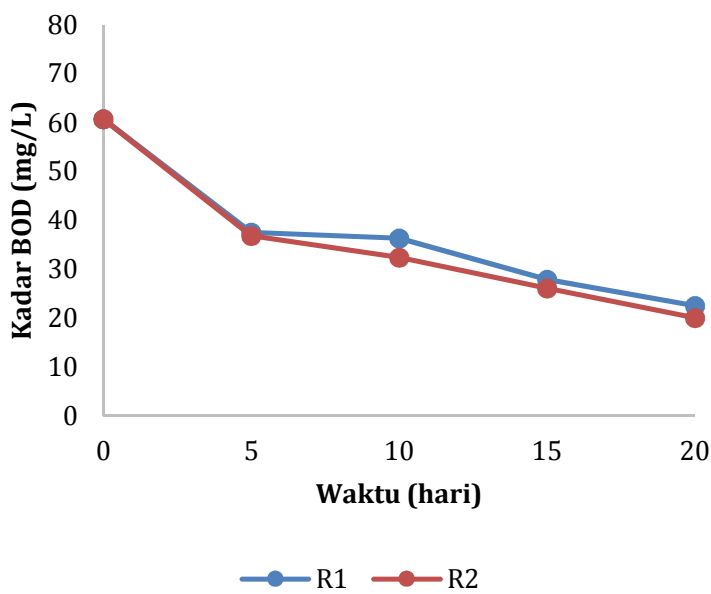

Gambar 3a. Penurunan Konsentrasi BOD 5 pada Reaktor Biosand Filter

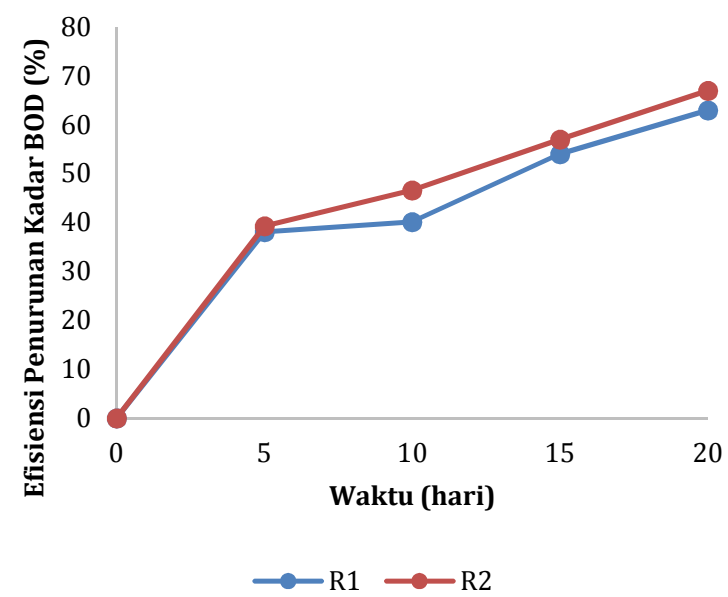

Gambar 3b. Efisiensi Konsentrasi BOD 5 pada Reaktor Biosand Filter

Keterangan: R1= kerikil:pasir halus:pasir kasar:karbon aktif $=(10: 10: 30: 10) \mathrm{cm}$ $R 2=$ kerikil:pasir halus:pasir kasar:karbon aktif $=(10: 10: 15: 25) \mathrm{cm}$

\subsection{Konsentrasi TSS pada Reaktor Biosand Filter}

Penurunan konsentrasi TSS pada kedua reaktor terlihat menurun dari awal sampai dengan akhir penelitian (Gambar 4a). Konsentrasi TSS pada hari ke-5 penelitian telah mencapai nilai yang memenuhi baku mutu berdasarkan Peraturan Menteri Lingkungan Hidup dan Kehutanan Republik Indonesia Nomor 68 Tahun 2016. Konsentrasi TSS pada hari ke-5 menurun tajam menjadi $37,00 \mathrm{mg} / \mathrm{L}$ dan $34,25 \mathrm{mg} / \mathrm{L}$ pada reaktor 1 dan 2 . Hari ke-5 sampai dengan akhir penelitian konsentrasi TSS perlahan menurun, dengan konsentrasi akhir TSS adalah 22,25 mg/L (reaktor 1) dan 18,55 mg/L (reaktor 2). Penurunan konsentrasi TSS pada reaktor biosand filter dikarenakan adanya proses filtrasi dan adsorbsi menggunakan butiran pasir halus (Lusela dkk., 2015). Bahan berbentuk suspensi akan terperangkap di lapisan saringan (Rahmi, 2016). Semakin kecil diameter pasir maka luas total permukaan media pasir akan semakin besar sehingga kemampuan untuk mengadsorbsi semakin baik (Widyaningsih, 2011).

Efisiensi penurunan konsentrasi TSS pada hari ke-5 penelitian sebesar 64,08\% (reaktor 1) dan 66,75\% (reaktor 2) (Gambar 4b). Di akhir penelitian, efisiensi penurunan konsentrasi TSS berturut-turut adalah 78,40\% dan 81,99\% untuk reaktor 1 dan 2 . Proses penurunan konsentrasi TSS ini terjadi karena adanya proses pengendapan dan resirkulasi sehingga dapat membantu menurunkan konsentrasi TSS dan juga terjadi karena banyaknya media karbon aktif yang digunakan dalam reaktor dan adanya lapisan biofilm yang berperan penting dalam menurunkan zat tersuspensi (Lusela dkk., 2015). Pada lapisan ini pengurangan zat tersuspensi disebabkan oleh mikroorganisme (Rahmi, 2016). Diameter, ketinggian media, dan waktu tinggal air limbah merupakan penentu keberhasilan biosand filter dalam menyisihkan konsentrasi TSS karena semakin panjang waktu tinggal air limbah pada reaktor, maka 
padatan tersuspensi yang terserap semakin tinggi oleh lapisan biofilm sehingga efisiensi penurunan TSS semakin tinggi.

Proses penyaringan padatan tidak efektif apabila diameter media terlalu besar, karena hanya sedikit zat tersuspensi yang akan terserap dalam rongga antar butir media (Widyaningsih, 2011). Diameter media yang terlalu kecil akan menyusahkan proses pemeliharaannya karena mudah terjadi clogging (Widyaningsih, 2011). Pada penelitian Lusela dkk. (2015) penurunan konsentrasi TSS limbah cair rumah tangga dengan biosand filter mampu menurunkan konsentrasi TSS sebesar 70,10\% karena kecepatan aliran yang rendah berpengaruh terhadap

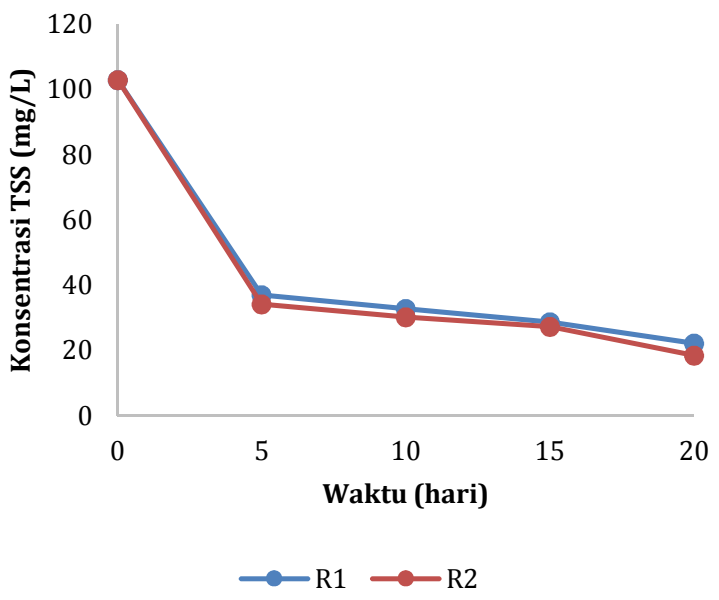

Gambar 4a. Penurunan Konsentrasi TSS pada Reaktor Biosand Filter waktu tingal limbah cair, sehingga akibat waktu tinggal yang lebih lama selama 21 hari maka lebih banyak padatan terlarut yang tertahan pada media filter.

Jika dibandingkan kedua reaktor, maka reaktor 2 mempunyai nilai efisiensi penurunan konsentrasi TSS paling tinggi dibandingkan reaktor 1 . Hal ini menunjukkan pada reaktor 1 kurang efektif karena pertumbuhan bakteri belum mencapai steady state sudah dilakukan running sehingga bakteri belum optimal dalam melakukan penyaringan konsentrasi TSS, sehingga reaktor 2 lebih efektif dalam menurunkan konsentrasi TSS dalam pengolahan air limbah domestik dengan biosand filter.

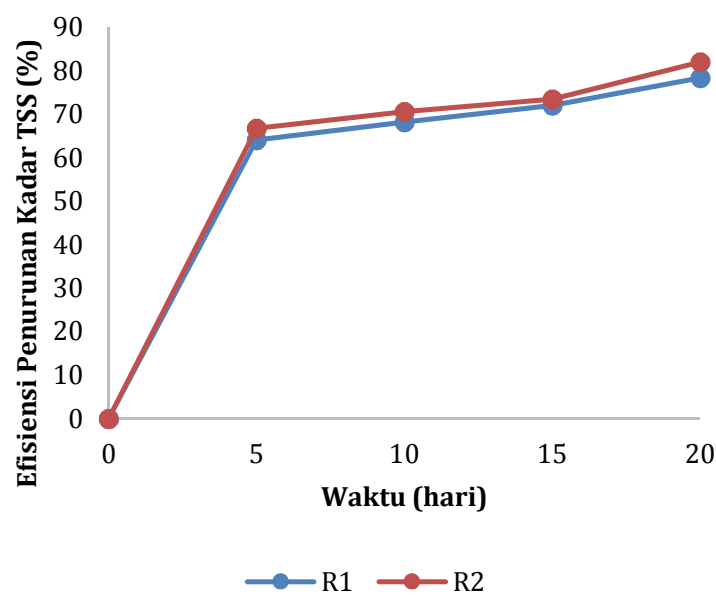

Gambar 4b. Efisiensi Konsentrasi TSS pada Reaktor Biosand Filter

Keterangan: R1= kerikil:pasir halus:pasir kasar:karbon aktif $=(10: 10: 30: 10) \mathrm{cm}$ $\mathrm{R} 2=$ kerikil:pasir halus:pasir kasar:karbon aktif $=(10: 10: 15: 25) \mathrm{cm}$

\section{Kesimpulan}

Kesimpulan dari penelitian adalah efisiensi penurunan konsentrasi BOD dan TSS pada reaktor 1 dengan susunan media kerikil:pasir kasar:pasir halus:karbon aktif adalah (10:10:30:10) cm berturut-turut adalah 62,92\% dan 78,40\%. Pada reaktor 2 dengan susunan media kerikil:pasir kasar:pasir halus:karbon aktif yaitu (10:10:15:25) $\mathrm{cm}$ mempunyai nilai efisiensi penurunan konsentrasi BOD dan TSS masing-masing adalah $67,01 \%$ dan $81,99 \%$. Variasi susunan media yang lebih efektif dalam menurunkan konsentrasi BOD dan TSS pada air limbah domestik adalah media kerikil:pasir kasar:pasir halus:karbon aktif dengan ketinggian (10:10:15:25) cm.

\section{DAFTAR PUSTAKA}

Ananda, dkk. (2017). Perancangan Alat Ukur Padatan Terlarut, Kekeruhan dan pH Air Menggunakan Arduino Uno. Laporan Tugas Akhir, Universitas Hasanuddin. Makassar.
Center for Affordable Water and Sanitation Technologies. (2010). Summary of Fields and Laboratory Testing for The Biofilter.

Gultom, E.M. dan Lubis, M.T., (2014), Aplikasi Karbon Aktif Dari Cangkang Kelapa Sawit Dengan Aktivator H3P04 Untuk Penyerapan Logam Berat Cd dan Pb, Jurnal Teknik Kimia USU, 3 (1), pp. 5-10.

Halim. (2014). Biosand Filter Dengan Reaktor Karbon Aktif Dalam Pengolahan Limbah Cair Laundry. Tugas Akhir. Teknik Lingkungan. FTSP. Makassar: Universitas Hasanuddin.

Hidayah, E.N., Djalalembah, A., Asmar, G.A., dan Cahyonugroho, O.H., (2018), Pengaruh Aerasi dalam Consturcted Wetland pada Pengolahan Air Limbah Domestik, Jurnal Ilmu Lingkungan, 16 (2), pp. 155161.

Jamilatun, S. dan Setyawan, M., (2014), Pembuatan Arang Aktif dari Tempurung Kelapa dan Aplikasinya untuk Penjernih Asap Cair, Spektrum Industri, 12 (1), pp. 1 $-112$.

Kholif, M. A. dan Ratnawati, R., (2016). Removal Ammonia $\left(\mathrm{NH}_{3}\right)$ di Industrial Chicken Slaughterhouse by Anaerobic Biofilter, Prosiding Seminar International the $1^{\text {st }}$ Seminar on Environment and Health Toward 
SDG'S Achievement 2030 Integration System on Environment and Health Sustainability, pp. 171-179, Surabaya.

Kholif, M.A. dan Ratnawati, R., (2017), Pengaruh Beban Hidrolik Media dalam Menurunkan Senyawa Ammonia pada Limbah Cair Rumah Potong Ayam (RPA), Jurnal Teknik WAKTU, 15 (1), pp. 1-9.

Kodoatie, R.J. dan Sjarief, R., (2010). Tata Ruang Air. Yogyakarta: ANDI Yogyakarta.

Kubare, M. dan Haarhoff, J., (2010). Rational Design of Domestic Biosand Filters. Journal of Water Supply: Research and Technology, 59 (1), pp. 1-15.

Lusela, Y.A., Prayogo, T.B., dan Haribowo, (2015). Studi Efektivitas Biosand Filter Terhadap peningkatan Kualitas Limbah Cair Rumah Tangga dengan Variasi Luas Permukaan dan Tinggi Freeboard. Skripsi Jurusan Teknik Pengairan Fakultas Teknik Universitas Brawijaya Malang.

Lynn, T.J., Wanjugi, P., Harwood, V.J., dan Ergas, S., (2013), Dynamic Performance of Biosand Filters, Journal American Water Works Association, pp. E587-E595.

Nurhayati I., Sugito, dan Pertiwi, A., (2018), Pengolahan Limbah Cair Laboratorium dengan Adsorpsi dan Pretreatment Netralisasi dan Koagulasi, Jurnal Sains dan Teknologi Lingkungan, 10 (2), pp. 125-138.

Nurhayati, I., Ratnawati, R., dan Sugito, (2019), Effect of potassium and carbon addition on bacterial algae bioremediation of boezem water, Environmental Engineering Research, 24(3): 495-500.

Nogarh, J.N., Sowunmi, F.A., Oluwafemi, A.P., Agyei, P.A., Nukpezah, D.N., Atewamba, C.T., (2015), Biosand Filter as a Household Water Treatment Technology in Ghana and its Ecobusiness Potential: An Assessment Using a Lifecycle Approach, Journal of Environmental Accounting and Management, 3 (4): 343-353.

Peraturan Menteri Lingkungan Hidup dan Kehutanan Republik Indonesia Nomor 68 Tahun 2016 tentang Baku Mutu Air Limbah Domestik.

Puspitahati, C. (2012). Studi Kinerja Biosand Filter Dalam Mengolah Limbah Laundry dengan Parameter Fosfat. Tugas Akhir Program Studi Teknik
Lingkungan Fakultas Teknik Sipil dan Perencanaan Institut Teknologi Sepuluh Nopember Surabaya.

Rahmi, A. (2016), Pengolahan Air Limbah menjadi Air Domestik Non Konsumsi dengan Variasi Karbon Aktif Biosand Filter, Jurnal Teknik Sipil Siklus, 2 (1), pp. 58-66.

Ratnawati, R. dan Kholif, M.A. (2018). Aplikasi Media Batu Apung pada Biofilter Anaerobik untuk Pengolahan Limbah Cair Rumah Potong Hewan. Jurnal Sains dan Teknologi, 10 (1): 1-14.

Ronny dan Syam, D.M., (2018). Aplikasi Teknologi Saringan Pasir Silika dan Karbon Aktif dalam Menurunkan Konsentrasi BOD dan COD Limbah Cair Rumah Sakit Mitra Husada Makassar. Higinie, 4(3): 62-66.

Samina, Setiani, 0., dan Purwanto. (2013). Efektivitas Instalasi Pengolahan Air Limbah (IPAL) Domestik di Kota Cirebon terhadap Penurunan Pencemar Organik dan E-coli. Jurnal Ilmu Lingkungan, 11 (1), pp. 36-42.

Suligundi. (2013). Penurunan Konsentrasi COD (Chemical Oxygen Demand) Pada Air Limbah Cair Karet Dengan Menggunakan Reaktor Biosand Filter Yang Dilanjutkan Dengan Reaktor Activated Carbon. Jurnal Teknik Sipil. 13 (1).

Ulfa. (2010). Pengaruh Lama Kontak Karbon Aktif Sebagai Media Filter Terhadap Persentase Penurunan Kesadahan $\mathrm{CaCO}_{3}$ Air Sumur Artesis. Jurnal Kesehatan Masyarakat Indonesia.

Utami, A.R., (2013). Pengolahan Limbah Cair Laundry Dengan Menggunakan Biosand Filter dan Activated Carbon. Jurnal Teknik Sipil Untan, 13 (1): 59-71.

Widyaningsih. (2011). Pengolahan Limbah Cair Kantin Yongma Fisip UI. Skripsi Program Studi Teknik Lingkungan Fakultas Teknik Universitas Indonesia Jakarta.

Ulum, G.H., Suherman, dan Syafrudin, (2015), Kinerja Pengelolaan IPAL Berbasis Masyarakat Program USRI Kelurahan Ngijo, Kecamatan Gunung Pati, Kota Semarang, Jurnal Ilmu Lingkungan, 13 (2), pp. 65-71.

Said, N.I., (2010), Metoda Penghilangan Logam Berat (As, $\mathrm{Cd}, \mathrm{Cr}, \mathrm{Ag}, \mathrm{Cu}, \mathrm{Pb}, \mathrm{Ni}$ dan $\mathrm{Zn}$ ) di Dalam Air Limbah Industri, JAI, 2(6), pp. 136 - 148. 